\title{
Effects of Water Regime on the Structure of Roots and Stems of Durum Wheat (Triticum durum Desf.)
}

\author{
Amina Labdelli, ${ }^{1,2}$ Ahmed Adda, ${ }^{1}$ Youcef Halis, ${ }^{2}$ and Samira Soualem ${ }^{1}$ \\ ${ }^{1}$ Laboratory of Agro-Biotechnology and Nutrition in Semi-Arid Areas, Faculty of Natural Sciences and Life, \\ University Ibn Khaldoun, BP 78, 14000 Tiaret, Algeria \\ ${ }^{2}$ Scientific and Technical Research Centre for Arid Areas (CRSTRA), BP 1682 RP, 07000 Biskra, Algeria \\ Correspondence should be addressed to Youcef Halis; youcefhal@gmail.com
}

Received 6 May 2014; Revised 23 July 2014; Accepted 25 July 2014; Published 17 August 2014

Academic Editor: M. Yasin Ashraf

Copyright (c) 2014 Amina Labdelli et al. This is an open access article distributed under the Creative Commons Attribution License, which permits unrestricted use, distribution, and reproduction in any medium, provided the original work is properly cited.

Yield improvement of durum wheat is considerably limited by the expression of environmental abiotic factors. Water deficits are one of these limiting factors. Plants develop various strategies to tolerate the effects of water deficit. Some of such mechanisms might occur in the root and stem systems. The present study aimed to investigate some anatomical traits contributing to the drought tolerance in the durum wheat. The anatomical variations of the meristem of roots and stems, as a response to water deficit, were evaluated. The results indicated that the enhancement of the intensity of water deficit was accompanied by profound structural changes in the piliferous zone of roots. Water deficit caused a significant decrease in the diameter of the newly formed adventitious roots, which can be explained by a reduction in the thickness of the cortical parenchyma, through the reduction of cell size. This action was usually a contrary effect in the principal adventitious roots. The study also showed that increasing the intensity of water deficit reduced the diameter of vessels in the primary xylem, thereby increasing the hydraulic resistance of roots and lowering the flow of sap.

\section{Introduction}

In Algeria, wheat is grown under rainfed conditions in the interior plains, particularly in the highlands of the country (semiarid bioclimatic zones). These areas are often subject to the effects of weather conditions (high temperature coupled with low rainfall), which affect the growth and development of grain and hence productivity $[1,2]$. In these areas, the temporal and spatial variability of drought are the most limiting factors facing the cultivation of durum wheat [3]. Water deficit plays a direct role in the physiology of plants. All physiological functions are not affected at the same time and on the same scale [4].

Improving the productivity of these species depends mainly on the availability and efficient use of water resources. The ability to quantitatively evaluate the performance of crop plants undergoing water stress is very important in research programs for the rehabilitation and improvement of the production in these conditions [5]. Varietal improvement and development of drought-resistant plants encountered the complexity in the mechanisms of drought tolerance. Detecting the multiyear variations in yields of species is not sufficient to precisely determine the reactions developed by this species. The analysis must be complemented by a better understanding of drought adaptation mechanisms in the plant.

According to some researchers $[6,7]$, the root system capable of extracting water from the soil is an essential feature for drought resistance. This feature is particularly important in cultures that regularly suffer from water deficits at the end of the growth cycle. Its impact is particularly high because it is directly involved in the efficient use of water during the stress conditions. According to LEPS [8], long water deficits result in progressive changes in the structure of plant. Growth reductions are one of the first manifestations of water deficit $[9,10]$. Growth reductions occur either directly through the decrease in the speed of growth by inhibiting cell division [11], reduction of the leaf surface and thus decreasing the turgor [12], and reduction of the total biomass production [13] or indirectly by reducing the number of leaf-bearing 
organs. Roots are the first organs detecting the water stress, in particular by their ends which are the main sites for water absorption [14]. However, there is a consensus on the fact that the roots are the organs whose growth is least affected compared to the aerial parts, vegetative and reproductive [15].

The present study is part of this trend of research. The main objective was to evaluate the anatomical traits of roots and stems involved in tolerance to water deficit. Ten varieties of durum wheat, grown in Algeria, were investigated. The study was based on determining the variations in dimensions of the peripheral and internal cells of the cortical parenchyma of roots. Both principal adventitious and newly formed adventitious roots in the neck of the plant were investigated. Additionally, the diameter of the conductive elements and the metaxylem parenchymal cells of primary stem bark were examined.

\section{Materials and Methods}

This study attempted to explain the adaptive functioning of roots and stems. The study focused on 10 genotypes of durum wheat (Triticum durum Desf.) [16]. The studied genotypes were Oued Zenati, Glory Montgolfier, Mohamed Ben Bachir, Hedba3, Ofanto, Simeto, Gta dur, Waha (CHAM1), Vitron, and Chen's. The plant material was provided by the Institute of Technical Crops (ITGC) of Tiaret and the National Center for Control and Certification of Seed and Plants (CNCC) of Sidi Bel Abbes (Algeria).

2.1. Experimental Approach. Seeds of the ten genotypes were disinfected and allowed to germinate in Petri dishes on absorbent paper dampened with water and placed in an oven set at $25^{\circ} \mathrm{C}$ for 48 hours. Sprouts were transplanted into $15 \mathrm{~cm}$ PVC cylinders of diameter and $30 \mathrm{~cm}$ of length, filled with a substrate consisting of a mixture of sand, soil, and organic matter in the respective proportions of $8: 3: 1$. The tests were conducted in a semiautomatic greenhouse temperature, diurnal and nocturnal maintained, respectively, at $20^{\circ} \mathrm{C}$ and $15^{\circ} \mathrm{C}$. The relative humidity was $70 \%$ and photoperiod was maintained at 12 hours perday.

The cylinders were arranged in three batches. All cylinders were irrigated to field capacity until the fourth leaf stage was fully differentiated. The irrigation system was then modified. A batch to be irrigated continues until the end of the experiment (SDH). The other two batches were performed by progressive watering which was stopped at 38 and 49 days for the lots $\mathrm{ADH} 1$ and $\mathrm{ADH} 2$. At each level of treatment, the genotypes were repeated ten times which were randomly arranged among the sample sites. The dose was determined by irrigation practiced daily weighed cylinder. The irrigation water was replaced every three days by a commercial nutrient solution (ACTIVEG kind).

2.2. Measurements. The measurements were made at the beginning-elongating. The soil was separated from the roots by a moderate stream of tap water. Roots were then washed in a tank prior to measurements. The anatomical parameters involved in the plant tolerance to water deficit were reported
TABLE 1: Analysis of variance of the anatomical parameters of the stem of the ten genotypes.

\begin{tabular}{lccc}
\hline Trait & Genotype effect & $\begin{array}{c}\text { Water } \\
\text { treatment } \\
\text { effect }\end{array}$ & $\begin{array}{c}\text { Genotype } \times \text { water } \\
\text { treatment effect }\end{array}$ \\
\hline Long epidermis & $123,36^{* * *}$ & $194,19^{* * *}$ & $156,43^{* * *}$ \\
Large epidermis & $14,43^{* * *}$ & $21,54^{* * *}$ & $34,62^{* * *}$ \\
Metaxylem & $14,43^{* * *}$ & $21,54^{* * *}$ & $34,62^{* * *}$ \\
Parenchyma & $9,11^{* * *}$ & $44,97^{* * *}$ & $4,19^{* * *}$ \\
\hline
\end{tabular}

*** Significant at $0.1 \%$.

for the root meristem and stems of two types, primary and newly formed. Root meristem structure was illustrated by freehand cuts performed at the piliferous area of roots and at the neck for the stem. Part of the piliferous area of the adventitious and newly formed main roots is removed and immediately fixed with a mixture of ethanol and acetic acid $(15 \mathrm{~V}, 1 \mathrm{~V})$ for $24 \mathrm{~h}$. The samples were then washed in running water and then dried by passing through a solution of $70 \%$ ethanol. Using a blade and under a binocular, we performed thin sections which were recovered and double stained with dye (alum carmine and methyl green) and topped with a cover-slip. Observations and measurements were made under a microscope equipped with a phototube and an ocular micrometer OPTIKA kind. The following measurements were carried out: the diameter of the peripheral and internal cells (PCP) of cortical parenchyma bark and root epidermal cell dimensions (length and width of the epidermis) and the diameter of the elements metaxylem conductors and that of the bark parenchyma cells of the primary shaft.

2.3. Statistical Analyses. All data were processed using the STATISTICA software package (StatSoft, Tulsa, USA). Comparisons between water treatments and between genotypes, within each water treatment, were based on the Duncan test at $5 \%$ probability level.

\section{Results}

3.1. Structure of the Stem. The statistical analysis of the tested parameters (Table 1) indicated that they were significantly influenced by the nature of the genotypes $(P<0.001)$, water regimes adopted $(P<0.001)$, and their interaction $(P<$ $0.001)$.

3.2. Length of the Epidermal Cells of Coatings. The dimensions involved in these steps were represented by the magnitudes of the diameter and the length of epidermal cell surfaces. Concerning the length, the obtained data were highly variable among the different genotypes and different water treatments. The evolution of this length based on the applied water regimes remained closely linked to the nature of the genotypes. Except in certain genotypes, increased water deficit culture substrate was accompanied by a marked decrease in cell length. The results (Table 2) showed that, in the batch $\mathrm{ADH} 1$, the evolution of the length was of various 
TABLE 2: The average results of the length and width of epidermal cells, recorded in different genotypes under three water treatments.

\begin{tabular}{lcccc}
\hline \multirow{2}{*}{ Variety } & \multicolumn{2}{c}{ Long epid. } & \multicolumn{2}{c}{ Large epid. } \\
& Evolution 1\% & Evolution $2 \%$ & Evolution $\%$ & Evolution $2 \%$ \\
\hline OZ & $-46,21$ & $-1,31$ & 28,04 & $-26,64$ \\
G-Mong & $-60,03$ & $-82,88$ & $-18,70$ & $-35,67$ \\
MBB & $-9,47$ & $-75,82$ & $-15,38$ & $-32,04$ \\
H3 & $-63,91$ & $-89,72$ & $-68,46$ & $-71,41$ \\
Ofanto & $-39,38$ & 5,33 & $-48,47$ & $-38,16$ \\
Simeto & $-68,27$ & $-17,08$ & $-38,71$ & $-56,71$ \\
Gta dur & 133,15 & 166,31 & $-9,65$ & 244,74 \\
WAHA & 198,75 & 25,31 & 136,70 & $-6,11$ \\
VITRON & $-60,21$ & $-16,36$ & 30,53 & 15,04 \\
Chen's & $-2,51$ & 9,81 & $-47,73$ & $-33,36$ \\
\hline
\end{tabular}

trends. Thus, the genotypes Gta dur and Waha showed an increase of 133.15 and $198.75 \%$, respectively. Other genotypes showed a regression of the length where Simeto represented the higher value of this development, with a rate of $68.27 \%$. In the $\mathrm{ADH} 2$ treatment, the responses of genotypes were different again. Genotypes Ofanto, Waha, Gta dur, and Chen's expressed the higher values of the length, while the remaining genotypes showed low values of the length, in which Hedba3 showed the higher rate of transformation with $68.27 \%$.

3.3. Cell Diameter Epidermal Coatings. The diameter differences of expression of epidermal cells (Table 2) were less pronounced than those of the length. In the ADH1 treatment, diameter values fluctuated between limits of 9.65\% (Gta Dur) and $136.7 \%$ (Waha). In the lot and $\mathrm{ADH} 2$ except Gta dur and Vitron in which there has been an increase in their diameter compared to that recorded in optimal conditions, the remaining genotypes showed regression in their diameter. Among these genotypes, Hedba3 had the largest decrease with a rate of $71.41 \%$.

3.4. Diameter of the Conductive Elements (Metaxylem). The results (Table 3) showed that the changes in the diameter at the ADH1 lot depended on the nature of the experienced genotypes. Thus, the group consisting of Ofanto, Simeto, and Gta dur showed a decrease in their diameter with values of $9.13,23.37$, and $5.38 \%$, respectively. A second group including genotypes showed an increase in their diameters (including Oued Zenati, Glory Mongolfier, Mohamed Ben Bachir, Hedba3, Waha, Vitron, and Chen's). In the ADH2 treatment, with the exception of the Waha, all genotypes showed significant reductions in their diameters. According to this trend, genotypes Gta dur and Hedba3 expressed the greatest reductions with rates of $70.20 \%$ and $57.75 \%$, respectively.

3.5. Parenchymal Cell Diameter. The influence of water regimes on the expression of this parameter depended essentially on the nature of the latter. The application of water deficit usually resulted in reducing diameters expressed in different genotypes. The average results (Table 3 ) indicated
TABLE 3: Average results of conductor diameters metaxylem elements and parenchyma cells, recorded in different genotypes under three water treatments.

\begin{tabular}{lcccc}
\hline \multirow{2}{*}{ Variety } & \multicolumn{2}{c}{ Metaxylem } & \multicolumn{2}{c}{ Parenchyma } \\
& Evolution 1\% & Evolution $\%$ & Evolution 1\% & Evolution 2\% \\
\hline OZ & 0,31 & $-45,88$ & 38,56 & $-28,15$ \\
G-Mong & 19,25 & $-41,08$ & 35,30 & $-33,99$ \\
MBB & 42,41 & $-9,40$ & 10,69 & $-18,93$ \\
H3 & 8,72 & $-57,75$ & $-9,18$ & $-27,06$ \\
Ofanto & $-9,13$ & $-22,11$ & $-21,08$ & $-30,07$ \\
Simeto & $-23,37$ & $-52,43$ & $-20,52$ & $-21,82$ \\
Gta dur & $-5,38$ & $-70,20$ & $-19,45$ & $-54,67$ \\
Waha & 7,79 & 12,45 & 30,09 & 0,13 \\
Vitron & 10,39 & $-31,10$ & 18,08 & $-47,42$ \\
Chen's & 3,13 & $-10,49$ & $-32,59$ & $-25,58$ \\
\hline
\end{tabular}

TABLE 4: Analysis of variance of root anatomical parameters of the ten genotypes.

\begin{tabular}{lccc}
\hline Trait & Genotype effect & $\begin{array}{c}\text { Water } \\
\text { treatment } \\
\text { effect }\end{array}$ & $\begin{array}{c}\text { Genotype } \times \text { water } \\
\text { treatment effect }\end{array}$ \\
\hline PCP RP & $14,8^{* * *}$ & $7,21^{* *}$ & $7,21^{* * *}$ \\
PCI RP & $8,74^{* * *}$ & $61,4^{* * *}$ & $5,88^{* * *}$ \\
PCP R Néof & $14,9^{* * *}$ & $2,36^{*}$ & $15,17^{* * *}$ \\
PCI R Néof & $5,65^{* * *}$ & $11,44^{* * *}$ & $6,51^{* * *}$ \\
\hline
\end{tabular}

${ }_{*, * *, * * *}$ Significance level of 5.1 and $0.1 \%$, respectively.

that in the ADH1 treatment, the diameter varied among different experienced genotypes. This collection was distinguished into two types. The genotypes showing a reduction in the diameter were represented mainly by Chen's with a regression rate of $32.59 \%$. In contrast, the second group showing an increase in the diameter was represented particularly by Oued Zenati which gave the highest rate of $38.56 \%$. In batch $\mathrm{ADH} 2$, changing diameters tended to decrease in almost all conduits genotypes. The genotype of Gta dur was characterized by the largest reduction rate of $54.67 \%$.

3.6. Structure of the Root. Statistical analysis of the results (Table 4 ) shows that the used parameters varied significantly depending on the tested genotypes $(P<0.001)$ and applied water regimes $(P<0.001)$. The interaction of these two factors also allowed highly significant variations in the results of these parameters $(P<0.001)$.

3.7. Diameters of Main Roots Parenchymal Cells. The statement of the main results in terms of adventitious roots (Table 5) indicates that changes at the ADH1 lot was of different magnitude. The increases were limited by $64.42 \%$ (Simeto) and $2.73 \%$ (Waha) to the peripheral cells, and they were of the order of $72.34 \%$ (Bashir Mohamed Ben) and $0.28 \%$ (Hedba3) for cells of the central region. The exception was raised by the genotypes Ofanto and Gta dur which, unlike the initial findings, showed regression of 
TABLE 5: The average results of the diameter of peripheral and internal cells of the cortical parenchyma of the main roots, recorded in different genotypes under different water treatments.

\begin{tabular}{lcccc}
\hline \multirow{2}{*}{ Variety } & \multicolumn{2}{c}{ PCP RP } & \multicolumn{2}{c}{ PCI RP } \\
& Evolution 1\% & Evolution $2 \%$ & Evolution $1 \%$ & Evolution $2 \%$ \\
\hline OZ & 4,71 & $-18,71$ & 7,21 & 80,00 \\
G-Mong & 20,21 & 25,52 & 28,94 & 48,42 \\
MBB & 14,97 & $-1,73$ & 72,34 & 52,35 \\
H3 & 22,14 & $-10,37$ & 0,28 & $-24,93$ \\
Ofanto & $-44,85$ & $-19,34$ & 14,19 & 68,43 \\
Simeto & 64,42 & 87,71 & 4,60 & 75,59 \\
Gta dur & 36,62 & 52,91 & $-7,42$ & 18,79 \\
Waha & 2,73 & $-22,29$ & 34,49 & 23,36 \\
Vitron & 15,65 & 14,07 & 61,99 & 121,01 \\
Chen's & 62,78 & 53,40 & 27,99 & 94,49 \\
\hline
\end{tabular}

the diameters of parenchymal cells. In the treatment $\mathrm{AD}$ $\mathrm{H} 2$, the changing tendency of these parenchymal cells was distinguished according to their positioning at the bark and among genotypes. On peripheral cell lines, the application of this intensity of water deficit has genotypic divergence in the development of this diameter, thus reducing the diameter of genotypes Oued Zenati (18.71\%), Mohamed Ben Bachir (1.73\%), Hedba3 (10.73\%), Ofanto (19.34\%), and Waha (22.29\%), while genotypes Glory Mongolfier, Gta dur, Simeto, Vitron, and Chen's showed increases at respective rates of 25.52, 87.71, 52.91, 14.07, and 53.4\%.

Regarding the parenchymal cells of the central region (Table 5), the trends were different from those found for the peripheral cells. However, the application of water deficit in such intensity $(\mathrm{ADH} 2)$ caused an increase in the diameter, except Hedba3 genotype, which exhibited a regression in its diameter under these conditions. For the groups showing an increase in their diameter, the genotypes Vitron, Chen's, and Oued Zenati were among the genotypes having the highest rates values of $121.01,94.49$, and $80 \%$, respectively.

3.8. Diameters of Newly Formed Roots Parenchymal Cells. The results of the newly formed adventitious roots (Table 6) indicated that the application of water deficit in these two intensities caused variations of the magnitude comparing to what was found in the control group.

Under the conditions of the less intense water deficit (ADH1), the increase in diameters was of different speeds for different genotypes and for the two positions of the cells. For the peripheral cells, the trend encompasses increases in some genotypes (Hedba3, Gta dur, Waha, Vitron, and Chen's) and decreases for others. The influence of water deficit in this form was generally an upper bound effect. Thus, genotypes Hedba3 and Vitron enroll in the highest rate of increases with values of 42.43 and $41.54 \%$, respectively. In this case the exception is given by Chen's which showed a regression of its diameter with a rate of $4.09 \%$. In processing the $\mathrm{ADH} 2 \mathrm{had}$ a regression tend to increase the diameters of the two types of cells. On peripheral cells, the action of water deficit has led to increases in genotypes Glory Montgolfier (5.3\%), Hedba3 (34.54\%),
TABLE 6: The average results of the diameter of peripheral and internal cells of the cortical parenchyma of the newly formed roots, recorded in different genotypes under different water treatments.

\begin{tabular}{lcccc}
\hline \multirow{2}{*}{ Variety } & \multicolumn{2}{c}{ PCP R Néof } & \multicolumn{2}{c}{ PCI R Néof } \\
& Evolution 1\% & Evolution $2 \%$ & Evolution 1\% & Evolution 2\% \\
\hline OZ & $-7,66$ & $-9,06$ & 34,13 & 48,23 \\
G-Mong & $-6,08$ & 5,30 & 22,25 & 3,40 \\
MBB & $-22,10$ & $-0,15$ & 5,58 & 61,76 \\
H3 & 45,60 & 34,54 & 42,43 & 18,90 \\
Ofanto & $-16,26$ & 98,37 & 16,13 & 53,00 \\
Simeto & $-7,67$ & $-13,29$ & 8,94 & $-46,44$ \\
Gta dur & 17,01 & $-10,13$ & 24,51 & $-8,23$ \\
Waha & 19,19 & $-40,06$ & 9,23 & $-16,50$ \\
Vitron & 32,15 & $-17,38$ & 41,54 & $-14,02$ \\
Chen's & 18,39 & 25,80 & $-4,09$ & 28,78 \\
\hline
\end{tabular}

Ofanto (98.37\%), and Chen's (25.8\%). The remaining six genotypes showed decreases in their diameters in which Waha was distinguished by the highest rate with $40.06 \%$. For internal cells, the largest number of genotypes showed increases in their respective diameters; only four genotypes showed lower values of this parameter where Simeto showed the largest decline with a rate of $46.44 \%$.

\section{Discussion}

Structural changes induced changes in cells and tissues, which can alter the growth behavior at different levels of organization. These alterations include the roots, stems, and leaves of stressed plants compared to control plants [17].

The study of these relationships allowed us to elucidate the relationships between the structural transformations of those roots and stems. According to the results (Table 7), it was shown that these effects have different impacts on the two groups of parameters. There were also no significant relationships between changes occurring at those roots and stems. Water deficit induced a significant reduction in cell size of various layers at the stem. Thus, the increase in the dryness of the substrate caused a net reduction of the length of epidermal cells $\left(r=-0.25^{*}\right)$, the diameter of the parenchymal cells $\left(r=-048^{* *}\right)$, and the diameter of the conductive elements metaxylem $\left(r=-0.49^{* *}\right)$. These results illustrated that the water deficit inhibits cell growth, which is justified by the loss of turgor of these cells. These results are confirmed by the work of Blum and Johnson [18], Huang and Redmann [19], and Kefu et al. [20] which showed that the water deficit resulted in a loss of turgor, thus minimizing the force from the turgor pressure. The reduction in cell growth might explain the inhibition of growth of organs in plants evolving under this constraint [21,22]. These structural transformations warrant confirmation with a reduction of the length of the last previously recorded between nodes of different genotypes subjected to these drought conditions $\left(r=-0.77^{* *}\right)$. The results therefore demonstrated that the observed reduction in force of the aerial part following 
TABLE 7: Relationship between water deficit and anatomical parameters of piliferous root zone and stem.

\begin{tabular}{lcccccccc}
\hline Variable & Long epid. & Large epid. & Metalaxyl & Parenchyma & PCP RP & PCI RP & PCP R Néof & PCI R Néof \\
\hline SH & $-0,25^{*}$ & $-0,2$ & $-0,49^{* *}$ & $-0,48^{* *}$ & 0,12 & $0,58^{* *}$ & 0,1 & 0,18 \\
Long epid. & & $0,66^{* *}$ & $-0,1$ & $-0,01$ & $-0,01$ & $-0,06$ & $-0,11$ & $-0,23^{*}$ \\
Large epid. & & & 0,01 & 0,08 & 0,08 & $-0,12$ & $-0,14$ & $-0,17$ \\
Metalaxyl & & & & $0,66^{* *}$ & $-0,23^{*}$ & $-0,27^{* *}$ & $-0,02$ & 0,08 \\
Parenchyma & & & & & $-0,28^{* *}$ & $-0,42^{* *}$ & 0,02 & 0,08 \\
PCP RP & & & & & & $0,28^{* *}$ & 0,16 & $-0,06$ \\
PCI RP & & & & & & & 0,05 & 0,08 \\
PCP R Néof & & & & & & & & \\
\hline
\end{tabular}

Numbers annotated with asterisks $*$ and $* *$ are significant at $5 \%$ and $1 \%$ levels.

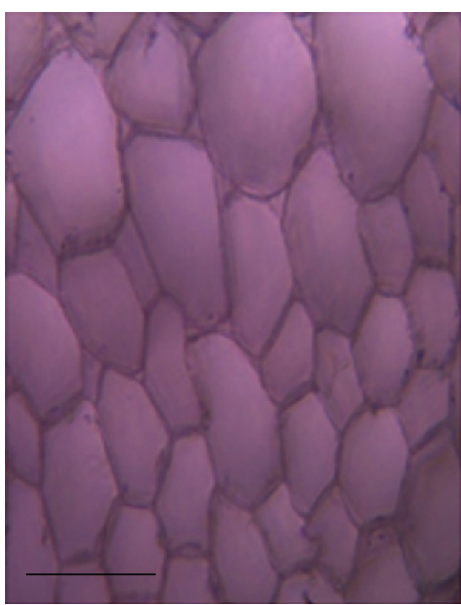

(a)

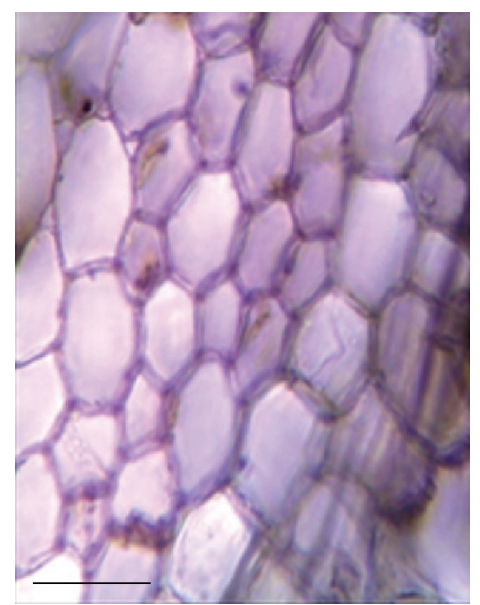

(b)

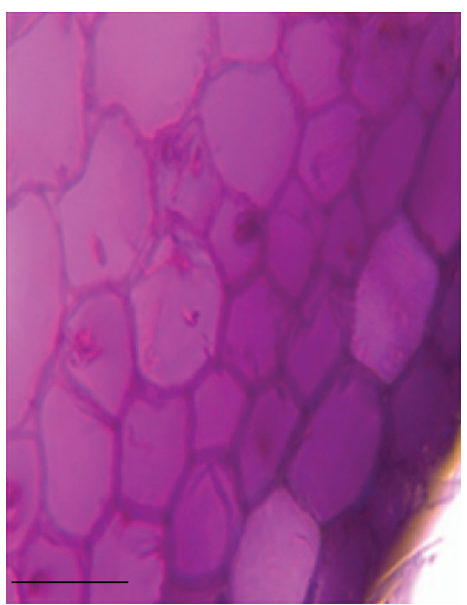

(c)

FIGURE 1: Anatomical structure piliferous area of cortical parenchyma of newly formed roots. (a) Without water deficit. (b) With water deficit 1. (c) With water deficit 2. Scale bars $=0.13 \mu \mathrm{m}$.

the declaration of water deficit could be explained by a reduction in the intensity of cell growth (Figures 1, 2, and 3).

The results demonstrated the effects of variable water deficit on the dimensions of parenchymal cells, depending on their locations. In the main roots, water deficit allowed a significant increase in the diameter of the cells of the central zone $\left(r=0.58^{* *}\right)$ and a small amount from that of the surrounding area. The dimensions of the root parenchyma cells of newly formed roots appeared to affect the nature of the water supply plant. These results demonstrated that the structural changes of the root portion were realized differently from that obtained at the stem part.

\section{Conclusion}

Research and study of adaptation parameters to water deficit are a key work in any attempt to improve the safety and productivity of durum wheat governed by water deficits areas. The effect of drought on the behavior of this species depends on its intensity and the time of the statement during the development cycle of the plant. Therefore, durum wheat offers significant levels of existing variability associated with tolerance to this constraint. The comprehensive study of the involvement of different strategies in the public tolerance and provisions for their transfer offer significant opportunities for successful creative work for more productive and tolerant genotypes under drought conditions. Variability represented by ten genotypes constituting the plant material in this study confirms this synthesis. The present study was based primarily on relationships of anatomical aspects, revealing significant variations of expression from the experienced genotypes.

The study showed that the applied water deficits cause profound anatomical changes in different vegetative organs involved in this study. Reactions of tolerance for preserving various aspects of root formation were noted in some genotypes and intermediate acuity accompanying the intensity of stress. Structural investigations of the roots and stems versus the water deficit showed strongly reduced cell volume, causing a reduction in growth rate, except the roots that were found to be a remodeling of the cell structure. Thus, the water deficiency caused cell growth in length of the different zones of the root structure and reduction in volume by limiting the growth and promotes the diffuse apical growth. These observations have been clarified through previous work and described as root hydrotropism observed especially in water conditions characterized by dryness of the ascending profile. 


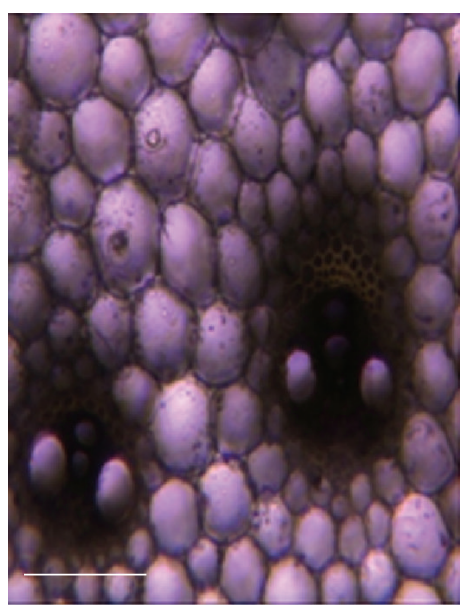

(a)

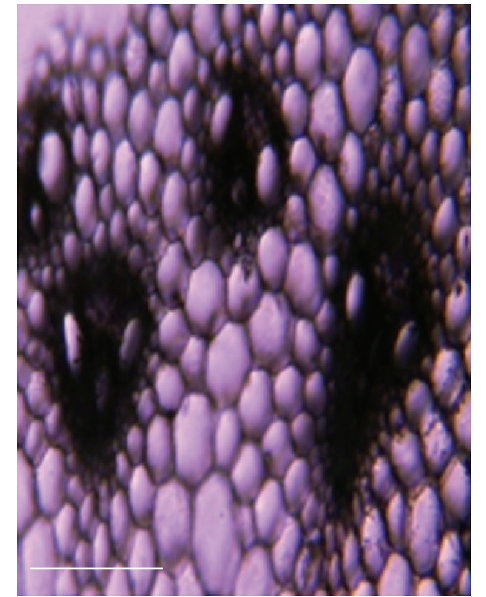

(b)

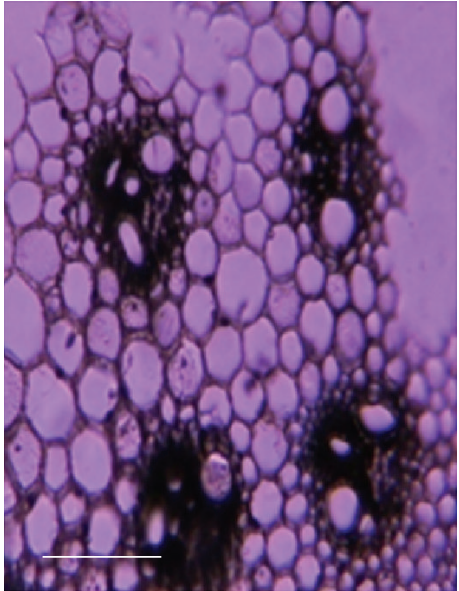

(c)

Figure 2: Anatomical structure of the stem. (a) Without water deficit. (b) With water deficit 1. (c) With water deficit 2. Scale bars $=0.49 \mu \mathrm{m}$.

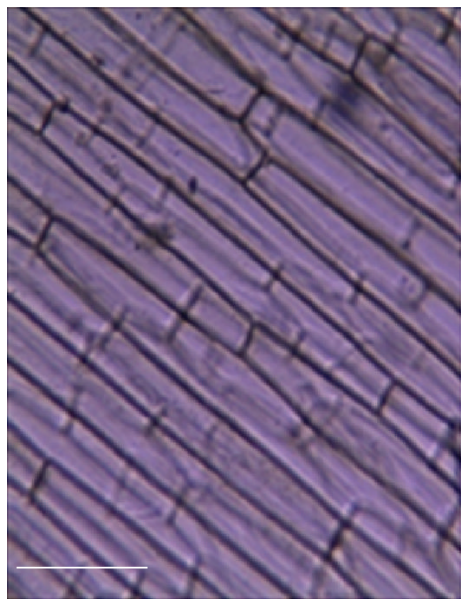

(a)

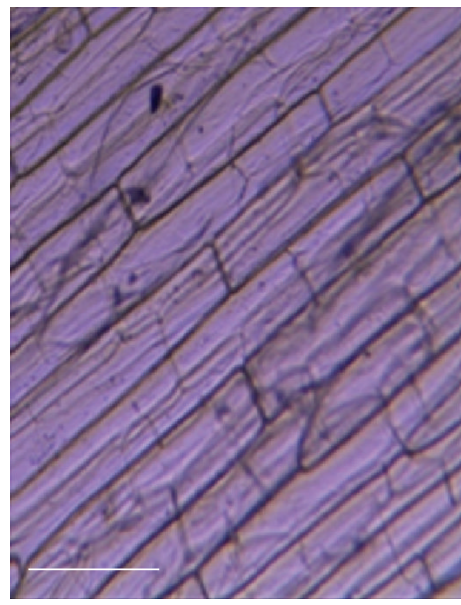

(b)

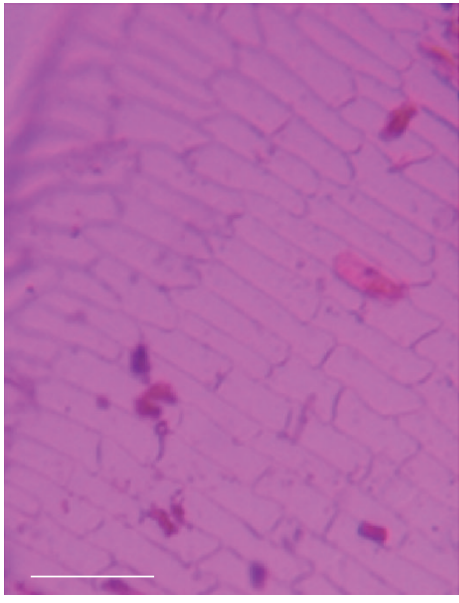

(c)

Figure 3: Anatomical structure of the epidermal stem cells. (a) Without water deficit. (b) With water deficit 1. (c) With water deficit 2. Scale bars $=0.49 \mu \mathrm{m}$.

\section{Abbreviations}

ADH: With water deficit

CC: $\quad$ Field capacity

$\mathrm{cm}$ : Centimeter

CNCC: National Centre for Control and Certification of Seed and Plants

End.: Endoderm

Epid.: Epidermis

F: $\quad$ Fisher test

H3: Hedba3

CETO: Institut Technique des Grandes Cultures

W: Width

OZ: $\quad$ Oued Zenati

PCI: Internal cortical parenchyma

PCP: Peripheral cortical parenchyma
R Néof: Newly formed roots

SDH: Without water deficit

$\mathrm{SH}$ : Water situation

$\mu \mathrm{m}$ : Micrometer.

\section{Conflict of Interests}

The authors declare that there is no conflict of interests regarding the publication of this paper.

\section{Acknowledgment}

This study was funded by the Scientific and Technical Research Centre for Arid Areas, CRSTRA (National Research Fund, FNR). 


\section{References}

[1] H. Bouzerzour, A. Benmahammed, A. Benbelkacem et al., "Stabilities and performance characteristics phenomenonsome morphological varieties of durum wheat (Triticum durum Desf.) from a selection multilocale," in Proceedings of the 1st International Symposium on Wheat Die-Challenges and Strategies, pp. 178-184, Algiers, Algeria, February 2000.

[2] L. Chair, A. J. Ferla, A. Honore, and R. Moukhli, "The impact of climate change on agriculture in Africa," in Proceedings of the ENPC Climate Change Workshop, 2005.

[3] P. Annicchiarico, Z. Abdellaoui, M. Kelkouli, and H. Zerargui, "Grain yield, straw yield and economic value of tall and semidwarf durum wheat cultivars in Algeria," Journal of Agricultural Science, vol. 143, no. 1, pp. 57-64, 2005.

[4] N. Brisson, "Modeling crop response to water stress with the STICS model to compare strategies and anticipate climate change," Technical Note Agroclim, INRA, Avignon, France, 2008.

[5] Plant Resistance to Drought, Centre Montpellier, INRA, 2000.

[6] J. L. Khalfaoui and J. Bull, "Genetic of adaptation to drought of cultivated species and consequences on plant breeding," Bulletin de la Société Botanique de France, vol. 137, pp. 125-137, 1990.

[7] G. V. Subbarao, C. Johansen, A. E. Slinkard et al., "Strategies for improving drought resistance in grain legumes," Critical Reviews in Plant Sciences, vol. 14, pp. 469-523, 1995.

[8] Laboratory of Ecophysiology of Plants under Environmental Stress (LEPS), Plant Resistance to Drought, INRA, Montpellier, France, 2000.

[9] P. J. Kramer and J. S. Boyer, Water Relationships of Plants and Soils, Academic Press, 1995.

[10] I. N. Saab and R. E. Sharp, "Non-hydraulic signals from maize roots in drying soil: inhibition of leaf elongation but not stomatal conductance," Planta, vol. 179, no. 4, pp. 466-474, 1989.

[11] C. Granier, D. Inze, and F. Tardieu, "Spatial distribution of cell division rate can be deduced from that of $\mathrm{p} 34^{c d c 2}$ kinase activity in maize leaves grown at contrasting temperatures and soil water conditions," Plant Physiology, vol. 124, no. 3, pp. 13931402, 2000.

[12] O. Bouchabké, F. Tardieu, and T. Simonneau, "Leaf growth and turgor in growing cells of maize (Zea mays L.) respond to evaporative demand under moderate irrigation but not in water-saturated soil," Plant, Cell and Environment, vol. 29, no. 6, pp. 1138-1148, 2006.

[13] A. Albouchi, Z. Bejaoui, and M. Hedi el Aouni, "Influence of moderate or severe water stress on growth of seedlings Casuarina glauca Sieb. Science and Global Change," Drought, vol. 14, no. 3, pp. 137-142, 2003.

[14] Y. Shimazaki, T. Ookawa, and T. Hirasawa, "The root tip and accelerating region suppress elongation of the decelerating region without any effects on cell turgor in primary roots of maize under water stress," Plant Physiology, vol. 139, no. 1, pp. 458-465, 2005.

[15] C. J. Soar and B. R. Loveys, "The effect of changing patterns in soil-moisture availability on grapevine root distribution, and viticultural implications for converting full-cover irrigation into a point-source irrigation system," Australian Journal of Grape and Wine Research, vol. 13, no. 1, pp. 2-13, 2007.

[16] F. Boufenar-Zaghouane and O. Zaghouane, Guide des principales variétés de céréales à paille en Algérie (blé dur, blé tendre, orge et avoine), ITGC, 2006.
[17] H. Reinoso, L. Sasa, M. Reginato, and V. Luna, "Histological alteration induced by sodium sulfate in the vegetative anatomy of Prosopis strombulifera (Lam) Benth," Word Journal of Agricultural Sciences, vol. 1, no. 2, pp. 109-119, 2005.

[18] A. Blum and J. W. Johnson, "Wheat cultivars respond differently to a drying top soil and a possible non-hydraulic root signal," Journal of Experimental Botany, vol. 44, no. 7, pp. 1149-1153, 1993.

[19] J. Huang and R. E. Redmann, "Salt tolerance of Hordeum and Brassica species during germination and early seedling growth," Canadian Journal of Plant Science, vol. 75, no. 4, pp. 815-819, 1995.

[20] Z. Kefu, F. Hai, Z. San, and S. Jie, "Study on the salt and drought tolerance of suaeda salsa and kalanchoe claigremontiana under iso-osmotic salt and water stress," Plant Science, vol. 165, no. 4, pp. 837-844, 2003.

[21] J. B. Bowne, T. A. Erwin, J. Juttner et al., "Drought responses of leaf tissues from wheat cultivars of differing drought tolerance at the metabolite level," Molecular Plant, vol. 5, no. 2, pp. 418429, 2012.

[22] P. Monneveux, D. Rekika, E. Acevedo, and O. Merah, "Effect of drought on leaf gas exchange, carbon isotope discrimination, transpiration efficiency and productivity in field grown durum wheat genotypes," Plant Science, vol. 170, no. 4, pp. 867-872, 2006. 

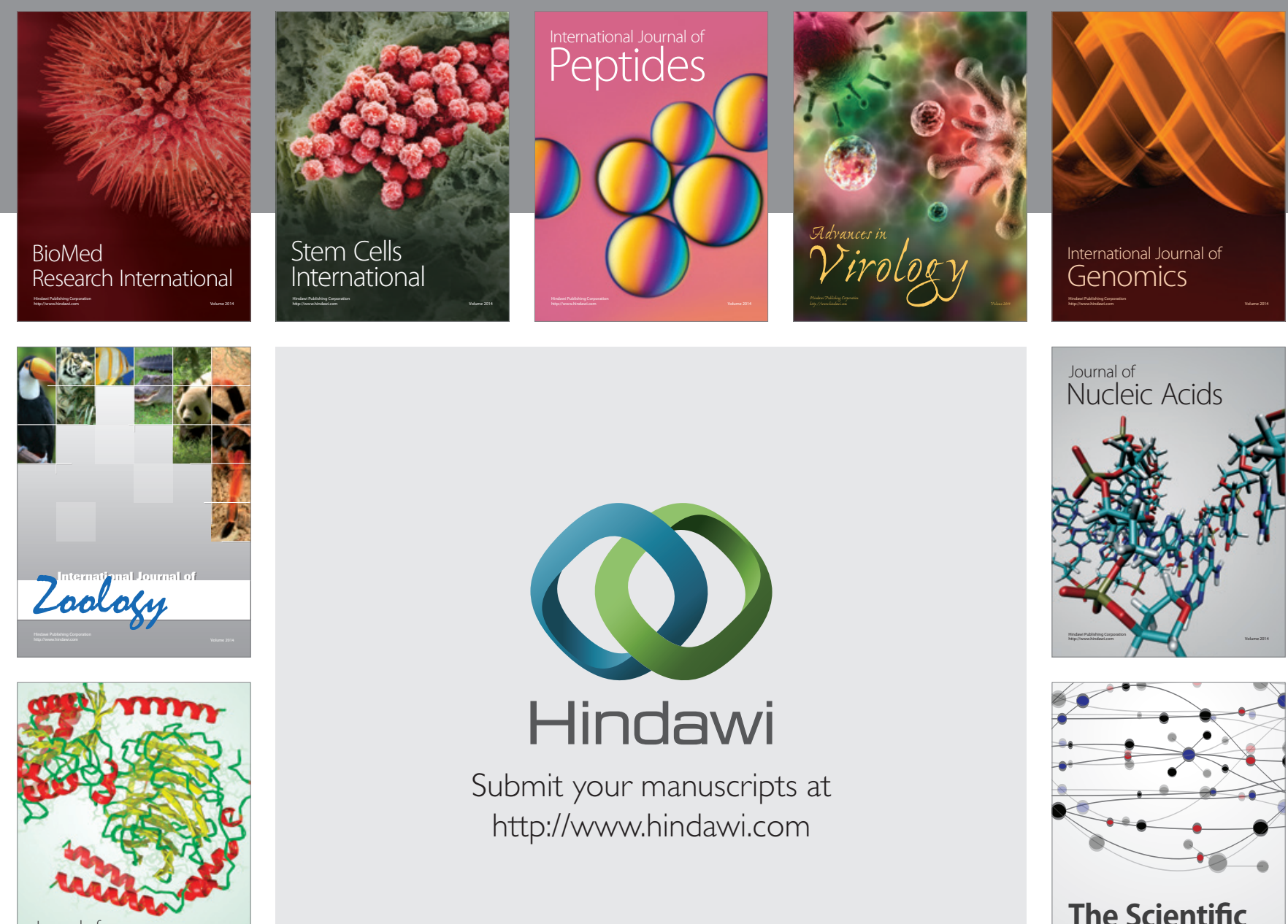

Submit your manuscripts at

http://www.hindawi.com

Journal of
Signal Transduction
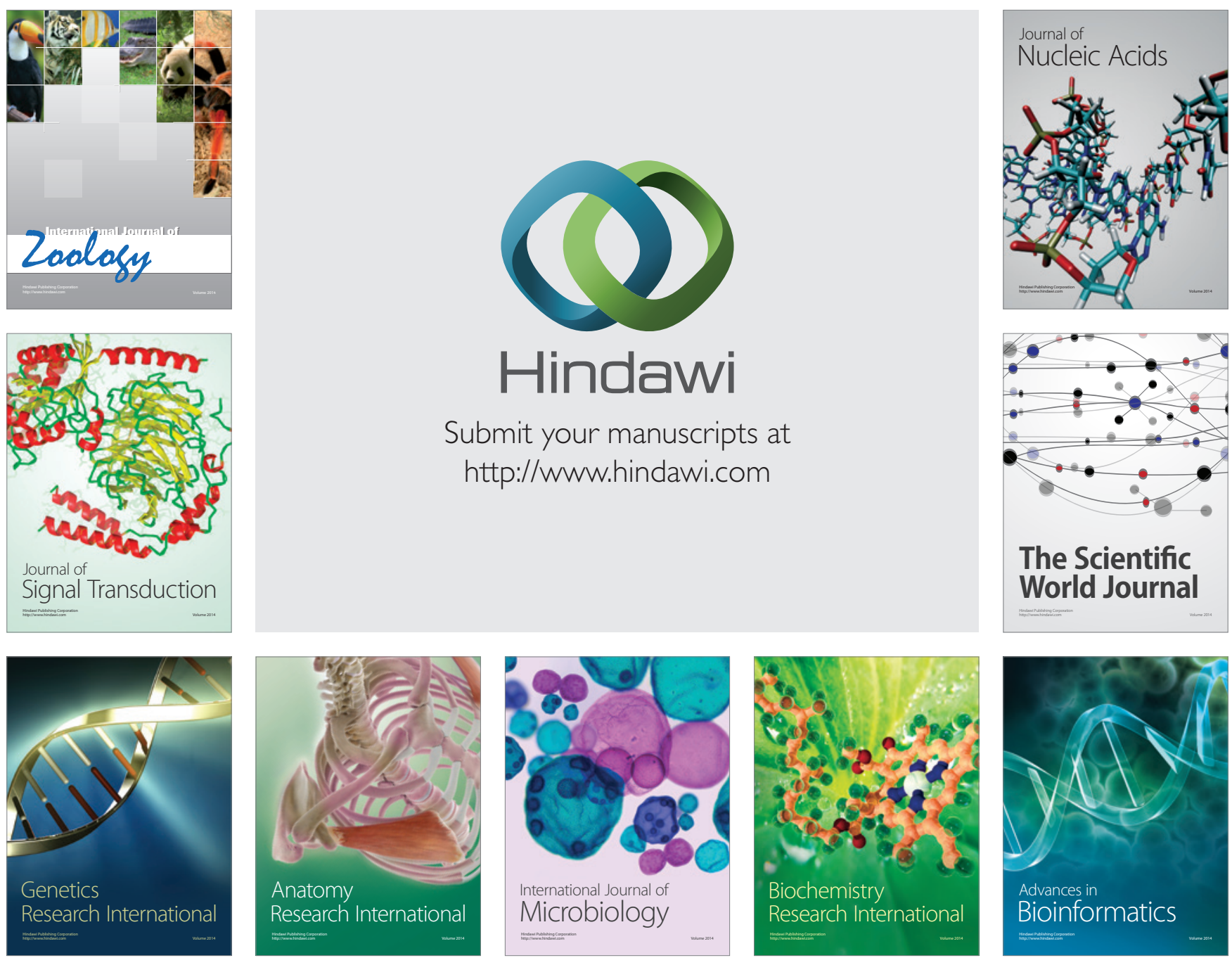

The Scientific World Journal
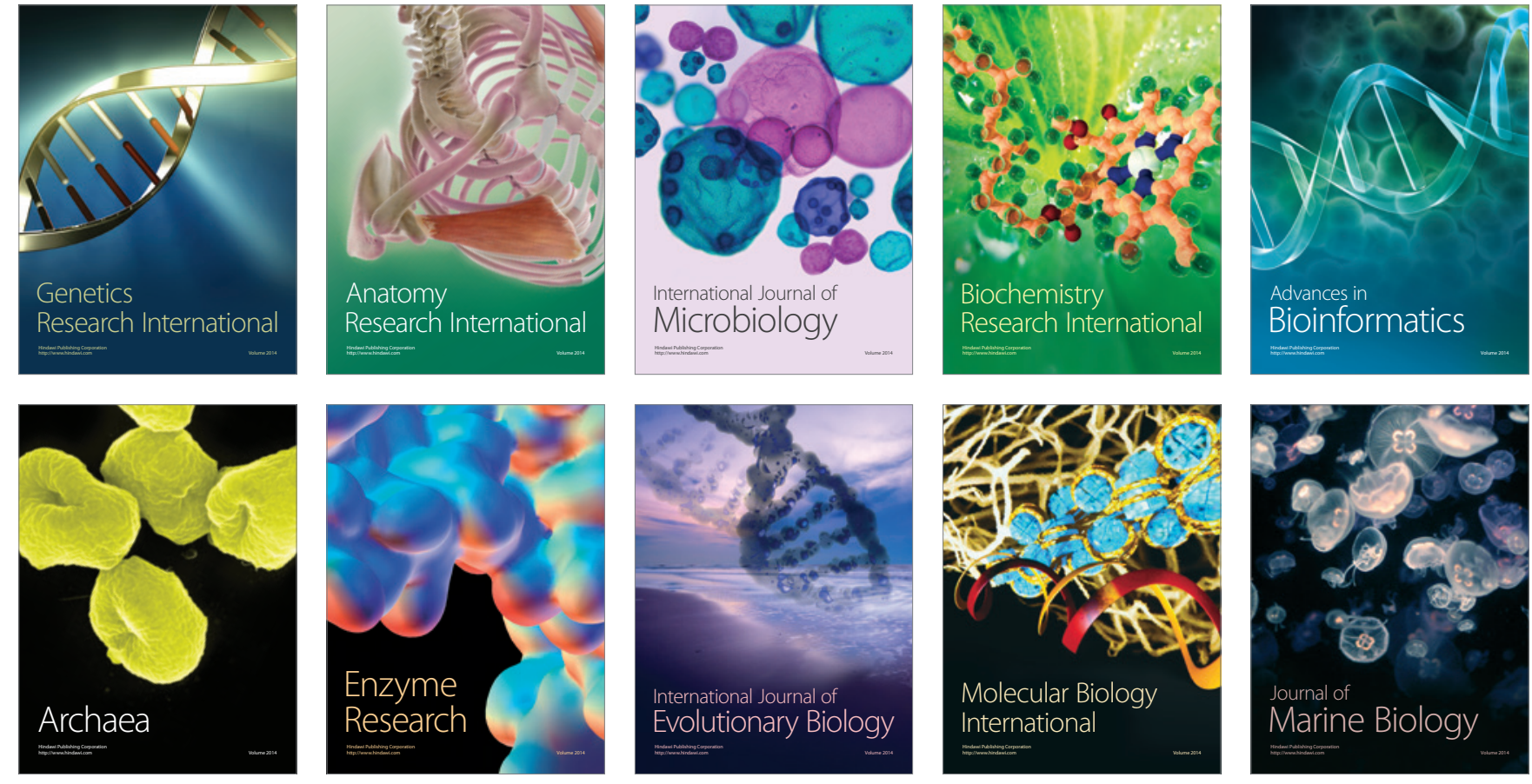